\title{
Mennesket i verden - som brud
}

Menneske! Hvor dybt du sukker,

Fryd dig ved Guds Velbehag!

Kjaerlighedens Billedhugger

I dit Ler har fundet Smag.

Har sit Liv i dit afbildet,

Drager det, i Død forvildet,

Atter kjarlig til sin Favn. ${ }^{1}$

\section{Af Synnøve Sakura Heggem}

I artikkelen Mennesket i verden som brud, viser jeg hvordan Grundtvig viderefører og fornyer tradisjonell bruderetorikk ut fra sitt menneskesyn, med vekt på kjønnsdifferensiert talemåte.

Innledningsvis skisseres Grundtvigs syn på mennesket i verden. Deretter skildres dette menneskesyn gjennom brudens mange ansiktstrekk. Vi møter den norrøne kjærlighetsgudinnen Freja i rollen som Kristi brud. Vi møter den nynnende, unge brud, den gamle brud, bruden som et mikrokosmos i relasjon til andre og verden. Vi møter henne som mann, og som prest, i en konkret, kirkepolitisk fromhetstale. Vi møter henne som mor, datter, og søster. Ikke minst møter vi henne som Guds Datter.

Grundtvig beskriver brudens svake sider, men ikke hennes uverdighet. Hvorfor ikke? Først og fremst fordi hun er attråverdig som et elsket og elskende vesen. Men også fordi Grundtvigs måte å tale om mennesket $\mathrm{i}$ verden på, utfordrer både brudens (mennesket) og brudgommens (Gud) ære i en relasjonell diskurs. Partenes skjebne er på en annen måte enn i tidligere og senere bruderetorikk knyttet til hverandre. $\AA$ kjempe mot verdens og menneskets ondskap, sier Grundtvig, forutsetter fordypelse i menneskets godhet, sannhet og skjønnhet. Bare slik erkjennes det onde på en fruktbar måte. Dette skaper en bruderetorikk av en særegen karakter.

\section{Hva er mennesket $i$ verden?}

Det gir tider og steder forskjellige svar på. Grundtvig ga sine. Men en ting er hva han selv skriver i filosofiske tekster som "Om Mennesket i verden" (Grundtvig 1817a, 118-207). Noe annet er hvordan jeg gjennom ulike tekster - oppfatter hans syn på mennesket $i$ verden. Brudebildene representerer en gruppe metaforer blant utallige, hvor hans menneskesyn kommer til uttrykk. Hva handler dette menneskesynet om? ${ }^{2}$

Mennesket er et guddommelig eksperiment, sa Grundtvig blant annet. I salmeretorikken eksperimenterer poeten seg fram til et billedegalleri med uendelige varianter av mennesket $i$ verden. Han 
spiller videre på bilder, modeller og forestillinger fra kirkenes og kulturenes (språksamfunn/sangskoler) skattkammere, nyformulerer og skaper sine egne bilder. ${ }^{3}$

Mennesket er først og sist et elskende og elsket vesen. Det henger sammen med at dets opphav, omgivelse, forbilde og mål er Gud, bestemt som kjærlighet. Det betyr samtidig at mennesket er bestemt som et relasjonelt vesen. Det kommer fra noe/n og retter seg mot noe/n. Som skapt av "Kjærlighedens Billedhugger" er det et kunstverk, samtidig som det ligner Gud som kunstner (Har sit Liv $i$ dit afbildet). ${ }^{4}$

Mennesket er et historisk vesen (kommer fra noe, i en sammenhengende prosess), er sted-egent (situert) og har et bestemmelsessted (prosessen går mot et mål). Det speiler i sin individualitet en historisk prosess. Det speiler kosmos, og er derfor betegnet som et mikrokosmos. Alt er representert i mennesket. Samtidig er alt det retter seg mot, preget av dets selvbillede og selvoppfattelse. Alle figurer i Grundtvigs salmer har noe representativt ved seg. Mennesket er en gåte for seg selv, men vokser i selverkjennelse og i erkjennelse av verden omkring. Det er også bestemt som bolig, redskap og speil; noe også menneskets ord er. Videre er mennesket Aand, Sjel og Legeme. Det ligner treenigheten, og tenkes som tre-delt i ulike metaforer.

Grundtvig bekrefter bare delvis vestlige tanker om mannen som det representative menneske. For han kommer stadig tilbake til sin påstand om at kvinnen er Grund-Mennesket, som han sier. Videre har han en form for androgynt ideal. Menneskebegrepet må være helheten av mann og kvinne.

Som sagt er mennesket relasjonelt, som en vesensbestemmelse. Det leser Grundtvig også ut av menneskets primære relasjoner i verden. Tre relasjonelle grunnmodeller går igjen: forholdet mellom foreldre og barn, mellom venner, og mellom ektefeller/kjærester. I hans tale om gudsrelasjonen utgjør disse primære, kjønnede relasjoner mellom mennesker hovedmodellene eller hovedlignelsene.

Mennesket er et kroppslig vesen. Det lever sitt liv på ulike arenaer, som det er knyttet til med affektive bånd. Det er et lyst-vesen. Grundtvig reflekterer over likheter og forskjeller mellom kvinnelig lyst, mannlig lyst og barnlig lyst. Det utfolder seg på en historisk arena. Det er del av en viten og visdoms-arena. Videre er det grunnleggende et musisk, poetisk vesen som utfolder seg på ulike estetiske arenaer. Naturen, verden, kosmos er ikke bare dets omgivelser, men også dets arenaer. I og gjennom alt er mennesket dermed en del av en hellig arena, preget av gavenes lover.

I dette gave-perspektiv er livskraften og lysten stadig overordnet tilintetgjørelse, krenkelse og død, og trenger Guds forsvar mot det som står sannhet, skjønnhet og godhet imot. ${ }^{5}$ 


\section{Brudens mange ansikt}

$\AA$ framstille menneskets hellighetsdimensjon i kraft av brudebilder representerer en svært gammel og velutviklet tradisjon. Katolsk mystikk og pietisme er to sterke bevegelser som har tradert brudebilder og erotisk terminologi. I disse tradisjoner finner vi en avansert og velutviklet relasjonstenkning som ikke viker tilbake for erkjennelser som nyere, mer vitenskapelige diskurser om menneskets relasjonalitet inneholder, som for eksempel de psykologiske, ulike litterære og kunsthistoriske. ${ }^{6}$

Grundtvig overtar, videreutvikler og kritiserer den tradisjonelle bruderetorikk. Han oppfattet bruderetorikkens status i samtiden som dunkel og uaktuell tale. ${ }^{7}$ Men han hadde tungtveiende grunner for å bekrefte og videreutvikle også denne retorikken. Han trengte den når han skulle tale sant, skjønt og godt nok om kirken og verden, om sine egne kvinner, om det som har vært, det som er og det som kommer. Han trengte den i klargjøring av menneskebegrepet, og for å bli klar over seg selv. Derfor kunne han ikke forkaste denne talemåte, men heller ikke overta den ukritisk. Han måtte fornye den, for han visste hvor galt det kunne gå når kjærlighetstale misbrukes, ikke minst $\mathrm{i}$ kirken.

Bruderetorikken er en del av Grundtvigs mytisk-historiske, religionsfilosofiske og eksistensielle kjærlighetstale. ${ }^{8}$ Bruderetorikken er en variant av relasjonsmodellen ektefelle/kjæreste (se over). ${ }^{9}$

Bruden har sin skjønnhet og makt fra sin status som elskende og elsket. Som brudgommen, har hun sitt liv i kraft av relasjonen til den andre. Likevel vil jeg fokusere på brudens ansikt og stemmer denne gang, og la brudgommen komme til syne og til orde i den grad det belyser bruden.

Bruden har mange forskjellige ansikt og masker. Vi møter kjærlighetsgudinnen Freja i rollen som Kristi brud. Vi møter den syngende brud, den gamle brud, bruden som et mikrokosmos - $\mathrm{i}$ hennes relasjon til verden og de andre. Vi møter bruden som mann (og brudgommen som kvinne). Vi møter bruden som prest i en konkret, kirkepolitisk fromhetstale. Vi møter barn av bruden. Vi møter de hindringer, skader og skuffelser bruden møter på sin vei ut fra og tilbake til det tapte paradis og sine mål: iscenesettelser av kjærlighetens seier over død og krenkelse. Vi møter brudens hjerte. Det er et hjerte som kjemper for sin vilje og rett til å elske Gud gjennom seg selv, de andre, verden. Vi møter hennes lengsler, lyster og behov; i likhet med og til forskjell fra brudgommens. 


\section{Freja som brud}

I norrøn mytologi fortelles det at kjærlighetsgudinnen Freja hadde et forhold til mennesket Ottar, og hevet dermed mennesket for en stund til gudestatus. Da Ottar ble borte for henne, savnet hun han så sterkt at hun gråt gulltårer. Det hun ubevisst, men dypest sett savner, er Kristus, slik Grundtvig tolker mytologien/fortiden ("Ham søgte du i Hedenold"). Slik kan han si det:

Ja, Danmark! du est Freia vist

Alt med sin Gylden-Taare,

Din Ægtemand er hviden Christ,

I Verdens Mund en Daare,

Ham søgde du i Hedenold,

Afmale skal du paa hans Skiold

Hans Æt og hans Bedrifter. ${ }^{10}$

Her ser vi blant annet at det er en analogi mellom Freja og Danmark.

$\mathrm{Vi}$ forholder oss til virkeligheten gjennom speilets og gåtens lov, mener Grundtvig. Uten å vite det alltid, gjetter mennesker på livsgåtene. Noen ganger løser de seg, og vi făr del i virkeligheten ansikt til ansikt, på en forløsende måte. Julegåten, at Gud ble ett med mennesket, var noe mennesker tidligere gjettet på gjennom kamp, lengsel og lyst (Gammen) inntil det skjedde. Slik sier Grundtvig det, med kjærlighetsgudinnen Freja som viktig aktør:

Ja, den favre Julegaade,

Som udraabes trindt om Land:

At Guds Sandhed og Guds Naade

Blev til ét, som Gud og Mand,

Gættes skal den her med Gammen,

Hvor sig slog mod Jætter sammen

Tor og Freja, As og Van. ${ }^{11}$

Det er Frejas evne til å gå inn i savnets krevende makt, som gir henne brudens verdighet. Hun elsket høyt, og savnet sterkt. ${ }^{12}$ Som Danmarkspersonifikasjon har hun høy status. Hun er også symbolisert i blomsten forglemmigej (kærminde). Den er samtidig symbol for en hvilken som helst "dannekvinne" (Toldberg 1950, 45). Fordi Freja også er Kristi brud, speiles skikkelser på mange ulike nivå.

Grundtvigs mettede symbolverden bringer til veie rike, kaleidoskopiske tekster som den lesende/syngende kan speile seg i, ikke minst i salmer som del av kristendoms og kulturformidling. ${ }^{13}$

Den gode løsning av gåten var at bruden var menigheten, eller Danmark; kollektive størrelser. I disse talemåter ser vi også Grundtvigs forsøk på å utligne de klassiske forskjeller mellom katolsk tra- 
disjon, kjent for kollektive former, og protestantisk tradisjon, kjent for individuell tenkning.

Selv om Grundtvig var direkte påvirket av katolsk østlig og vestlig kvinnefromhet, ironiserer han over de private nonne-drømmer om å være utvalgt brud:

Det drømde saa tit en Nonne-Sjæl

At Bruden var hun reenlivet

Og havde i Kiødet kun sin Pæl,

Til Anger og Bod hengivet,

Som havde Vorherre og hans Aand

Et Harem iløn, lig Salomon,

Af Nonner med Slør og Bælte! ${ }^{14}$

Når alle, også de alminnelige nabokoner, har noe vesentlig til felles med bruden (som dansk, som menighet, som del av fortiden ved å speile seg i Frejas kjærlighet, savn og tårer $\mathrm{mm}$ ); flyttes brudeverdigheten ned på et allment nivå. Alle mennesker har noe av bruden $\mathrm{i}$ seg, i likhet med de sterke symbolbærere som for eksempel Freja. Freja har altså noe vesentlig til felles med det helt alminnelige menneske, slik Kristus også har. Grundtvig ivaretar på denne måten det kollektive og det individuelle i nye varianter.

\section{Den syngende mor og nynnende, unge brud}

Vi møter bruden i "Christi Kirke, lydt du kvæde", en gjendiktning av en latinsk hymne, "Psallat ecclesia, mater illibata" (GSV I, nr. 350).

Slik en mor synger, slik bruden nynner, synger kirken til ære for den andre og sine egne roller og egenskaper i verden:

Christi Kirke! lydt du kvæde,

Som en Barne-Moder prud!

Sagte nynne du med Glæde,

Som den unge Brud!

Stærk og gammel, ung og viis,

Det er du til Herrens Priis:

Evig Drot, som Engle hylde,

Født i Tidens Fylde!

Hvorfor synger bruden? Hvordan viser mennesket $i$ verden seg gjennom brudens moderlig, syngende og den unges nynnende lykke?

Det begynner med stemme, røst, ånde, ord, sansning, lyd, bevegelse, berøring. Når mennesket synger, sier Grundtvig, har det en særlig god mulighet til å bli delaktig i sitt eget indre univers, og i andres; til sammen et symbolsk univers med universelle dimensjoner $i$ en ekspressiv form. Når mennesket synger, flyr det på vinger, i fri flyt: 
Min Sjæl, du har af alt paa Jord

I Tanken og din Tunges Ord

De allerbedste Vinger,

Og friest er dit Aandefang,

Naar dybt du drager det i Sang,

Saa høit i Sky det klinger. ${ }^{15}$

At sangen speiler en usynlig virkelighet, en evig godhet, er Grundtvigs gjentatte påstand. Når det evige ord møter menneskets, skjer det en kjærlig sammensmeltning, ikke ulik den unge brudens lykkelige tilstand, som elsket og elskende:

Ja, saavist som Gaade-Ordet

I Begyndelsen var Gud,

Al Dets Odel, om end jordet,

Skal opstaae paa Torden-Bud!

Som Dets Himmel-Røst er Torden,

Saa er Sang Dets Røst paa Jorden,

Vist i Evighedens Gry

Begge mødes høit i Sky,

Smelte kiærlig sammen! ${ }^{16}$

En ung brud nynner av glede over sin tilstand. Hva mer har gleden med selve sangakten å gjøre? Sang åpner for glede på en måte som gjør at den så å si kommer til orde eller finner sitt sted. Som syngende menneske $i$ verden er den nynnende, lykkelige brud et uttrykk for det å åpne munnen og gi gleden stemme, pust, lyd, ord. Når man synger sin kjærlighet til den andre, føler man bedre gleden, over seg selv, andre og verden som hellig virkelighet. Slik kan Grundtvig si det, her i jeg'ets kjærlighet til den andre, som Gud:

Giv mig, Gud, en Psalme-Tunge,

Saa for Dig jeg ret kan sjunge,

Høit og lydelig!

Saa jeg føle kan med Glæde,

Sødt det er om Dig at kvæde

Uden Skrømt og Svig! ${ }^{17}$

Det å åpne munnen for å gi gleden stemme, er nært forbundet med å åpne for tårenes tale. Å være til og å vokse som menneske i verden, er i Grundtvigs retorikk betinget av at vekslingen mellom sang og grăt er til stede. Han vet altfor godt at grensen mellom fryd og fortapthet er såre kort; og samtidig muliggjør at hjertebunnen făr væte, slik at noe kan feste rot og vokse videre. Den nynnende brud er gjennom stemmen forbundet med gråten, både slik vi så det hos Freja, og slik det alltid er. Når det syngende og det gråtende element i Grundtvigs pedagogisk pregnante talemåte forbindes, kan det se slik ut: 
Væxt vi alle har behov,

Levende dog, Gud skee Lov!

Stamme vi i Aanden:

Kommer Tid, da kommer Raad,

Stemmen giennem Sang og Graad

Styrkes efterhaanden. ${ }^{18}$

Den unge, nynnende brud visste mye om sin lykkelige og maktfulle brudestand. Hun visste også at den var skapt av forholdet mellom sang og gråt. Men hun hadde kanskje til gode å kjenne dybden i de prøvelser livet gir.

\section{Den gamle brud}

Det vet den gamle bruden alt om. Hun holder nesten ikke ut. Men hun vet likevel hva som skal til. Det ser vi i salmen "Christi Kirkes Alderdom" (GSV I, nr. 105). Her møter vi mennesket $i$ verden som gammel brud. Fiendemaktene, det som står kjærligheten mellom brud og brudgom imot, truer og krenker, tapper for krefter. Bruden er med god grunn utmattet, redd for den svakhet både kampen, freden, troen og kjærligheten er merket med (1-3). Hun er redd for ytre og indre avmakt som kan gjøre henne, han og forholdet til intet og til skamme. Likevel klarer hun å motstå fristelsen til å gi helt opp. Hun samler seg til en henvendelse etter å ha klargjort situasjonen. Hun henvender seg - igjen - til sin store kjærlighet, med begrunnet bønn om at brudgommen må vise seg fra sin beste side; verken svikte seg selv eller henne. Vi'et i salmen ber brudgommen enda en gang om å vise sin evne til å se henne (Varm Du hende med din Mund), så hun kan holde ut, tåle motgangen så lenge det er nødvendig; helt til brudelykken er sikret i et himmelsk trygt rom (4-7). Slik kjemper hun tappert for sin brudeverdighet. Slik argumenterer hun overfor brudgommen med sin egen utmattelse, det de har felles, løftene og ikke minst hans egen ære: "Det giælder og din Ære!” (4)

I salmenes mimetiske speilingskabinett går det veier mellom de ulike figurer. Noen er påtagelige, andre må man lete etter. En likhet mellom den gamle brudens vilkår og kjærlighetsgudinnen Freja, går gjennom deres felles vilkår som "Enkekvinde". Mens brudgommen tøver, lar det dra ut, lærer hun seg med hjerteskjærende tålmodighet kunsten å øve seg med et smil mens hun venter på det høyeste gode, som hun vet og kjenner fra før, og samtidig har til gode å oppnå som endelig sikring av brudelykken:

Her, hvor, som en Enkekvinde,

Hjærtensvennen tro og huld,

Freja, Taarerne lod rinde 
Som en Strøm af røden Guld,

Her, imens Brudgommen tøver,

I Taalmodighed sig øver

Bruden med et yndigt Smil! ${ }^{19}$

Kjærlighetens vilkår er de samme for alle, for bruden er prototyp for mennesket $i$ verden hos Grundtvig. Kunsten å elske er den høyeste kunst. Den krever alt, og gir alt. Til slutt "evig Fryd og Ære", ${ }^{20}$ skal vi tro forfatteren.

\section{Kan bruden vore mann?}

Hvordan kan hun i så fall være det? Det er hun når mannen gir sin brudelykke stemme og form ved å speile seg i bruderetorikken. Mannen som del av noe alment (eksempelvis det danske) eller som kristen (det religiøse menneske), er brud.

I den grad Grundtvigs eget jeg speiler seg i hans dikteriske jeg, er han også brud, kvinnelig. Det har han stor glede av. Det trenger han for å komme på en type kloss hold til Gud (som mann) som han ellers ville måtte stå utenfor. ${ }^{21}$ Slik er det også andre veien. For å komme nær Gud, trenger kvinnen å leve seg inn i mannens måte å være relatert til noe/ $n$ andre på. Gjensidig speiling er middelet. Målet er å bli et helt menneske i verden (summen av mann og kvinne) i relasjon til andre. I en preken med bruderetorikk, kan argumentasjonen se slik ut når mannen speiler seg i brudens hjerte:

Thi der er hverken Mand uden Kvinde eller Kvinde uden Mand i Herren, fordi i ham er alt menneskeligt som alt guddommeligt, og alle skal vi see med hans Øine og i hans Lys, som er Aanden. Og alle skal vi troe som Kvinder af og med Hjertet, som i Mennesket er Livets Kilde, saa de troende Kvinder i Herrens Følge med deres barnlige Tillid, deres ømme Hengivenhed, deres uophørlige Længsel, deres dybe Ydmyghed og vidunderlige Kiærlighed er Hjerte-Speilene, hvori vi alle skal betragte Herrens Aasyn og vores, er de Perler og Ædelstene, som vi alle skal lære at skatte, stræbe at vinde og omhyggelig giemme, som de Smykker, hvormed den hele Menighed skal pryde sig for Herren, som en Brud for sin Brudgom (Begtrup 1924, 226-227).

Grundtvig tenker at alt som er menneskelig har sitt opphav og speilbilde i det guddommelige. Når det sant menneskelige speiler seg i det sant guddommelige, og det sant guddommelige speiler seg i det sant menneskelige, er vi ved kjernen $i$ talen om mennesket $i$ verden. Slik konkrete mennesker er far, mor, sønn og venn osv. speiler det en guddommelig virkelighet som også karakteriseres på samme måte (se siste strofe). Alt i verden har sitt speilbilde i det guddommelige (se første strofe): 
Derfor Himmeriges Rige

Lignes kan ved Alt paa Jord,

Derfor og kan Støv og Aske

Med sin Skaber skifte Ord!

Ligned Legemet ej Aanden

Og ej Mennesket sin Gud;

Spildt var da al Aabenbaring,

Naadens Røst og Lovens Bud

Da var vi for Gud Barbarer,

Han Barbar for os igjen.

Aldrig da vi fandt i Himlen

Fader, Moder, Søn og Ven. ${ }^{22}$

Gud som subjekt, som objekt (den andre), som opphav, omgivelse og mål, som annerledes og som lik, forestilles i de former vi kjenner fra livet, sier Grundtvig. Det gjelder også f.eks. forestillingen om Gud som totalt annerledes. Det er en forestilling som også kjennes fra livet. Hvis ikke, ville vi ikke kunne gi det navn av "totalt annerledes".

Kristus er uten tvil brudgommen framfor alle. Han er først og fremst mann. Men Grundtvig tenker samtidig at om Kristus skal være prototypt menneske, må han både ha mann og kvinne i seg:

Herren kunde ikke være det fuldkomne Menneske, uden i Grunden at være baade Mand og Kvinde, og kun det fuldkomne Menneske er i alle Maader skabt i Guds billede og efter hans Lignelse (Stevns 1950, 73).

I sin likhet med Kristus (gudbilledlig/etterfølgelse/representativt), ligner kvinnen Kristus som utpreget forskjellig. I sitt forhold til Kristus som brud elsker hun han som kvinne til mann. Selv om han også kan oppfattes som kvinne (se over). Med andre ord: mannen og kvinnen ligner Kristus på forskjellige måte, slik de også elsker Kristus som brud på forskjellig måte. Dette kommer f.eks. til uttrykk i følgende sitat:

og derfor kunde Guds Søn kun sige til den troende Mand: dig ske, som du tror! Men til den fuldtro Kvinde: dig ske, som du vil! Derfor kan endelig Mennesket i mandlig Skikkelse kun som Johannes den Døber blive Frelserens Ven, og kun i kvindelig Skikkelse blive eet med ham, ligesom han er eet med sin Fader (Brandt 1880, 261-263).

Legg også merke til at den forening som er mulig mellom kvinne og mann (bli ett), er analog til det som forbinder Frelseren med sin Fader.

Grundtvigs store fortjeneste er at han reflekterer en kjønnet tale i kristendommens dogmatikk og ekklesiologi, og dermed inviterer til fortsatt refleksjon over betydningen av en slik tale.

I forbindelse med bruderetorikk og gudbilledlikhet er han styrt av sin viten om og frustrasjon over at det prototype menneske i verden $\mathrm{i}$ 
overdreven grad har vært mannen. Det vil han endre, også gjennom bruderetorikken. Resultatet er at han rokker både ved menneskebegrepet og ved gudsbegrepet.

En måte å uttrykke endringen i gudsbegrepet på, er den Magnus Stevns viste med følgende ord allerede i 1950:

$\mathrm{Nu}$ hedder Jomfru Marie ikke mere Guds-Moder; men over hendes Alter bygges et andet for en Gud-Moder, der som Gud-Fader er Part af Helheden Gud (Stevns 1950, 84).

Denne innsikt er i påfallende liten grad fulgt opp i Grundtvigforskningen og dogmatisk refleksjon knyttet til denne.

\section{Brudens søsterlige, datterlige og moderlige ansiktstrekk}

Vi møter brudens ansiktstrekk som søsterlige, moderlige og datterlige i Grundtvigs retorikk. I en poetiske hyllest til de tre kvinner han var gift med, ser vi hvordan han spiller på denne retorikken for å karakterisere brudenes ulike ansiktstrekk:

Søsterlig var min første Viv,

Duftende sødt som Violen,

Sjælden et mer idyllisk Liv

Leves der nu under Solen,

End, under smaa men smukke Kaar,

Vores fra Jul til Efteraar.

Moderlig var min anden Viv,

Funklende som Ædelstenen,

Det var et boldt romantisk Liv,

Artemis spandt paa Guldtenen:

I hendes Skjød, et Barn paa ny,

Sang jeg og græd i højen Sky!

Datterlig er min tredje Viv,

Svævende for mig som Feen,

Det er et aventyrligt Liv,

Roser udspringe paa Sneen:

Ungdom og Ælde lege Skjul,

Lege om Kys og Kage Jul! ${ }^{23}$

At Grundtvig ikke nøler med å holde metaforisk sammen egen kjærlighet, bruderetorikk og kirkens alminnelige tale om prest og menighet, er kjærlighetsvisa til Marie Toft, hans andre kone og største kjærlighet, et godt eksempel på: 
Hvad er det, min Marie!

Som gjør det, at vi to,

Vi tale eller tie,

Paa Færde og i Ro,

Os føle viet sammen,

Som Kirken og dens Amen,

Som Præst og Menighed!

Det er, at vi vil være

Hinanden, som vi er,

Det er, at vi kan bære

Hinanden, som vi er,

Det er, at vore Munde,

Vi vaage eller blunde,

Dog mødes i et Kys!

Kun paa en egen Maade

Vi er i Grunden ét,

Vort Liv var os en Gaade,

Til vi opdaget det,
Men nu har vi opdaget,

I Hjærte-Favnetaget

Vort Liv er fælles Lyst!

$\mathrm{Nu}$ er det kun en Gaade

For os at tænke paa

Hvordan vi af Guds Naade

Kan evig leve saa,

Thi uden Ny og Næde

Kun varer Liv og Glæde,

Al Synd og Død til Trods!

Derfor vi os forbinder

I Tro og Kjærlighed

Med Dødens Overvinder,

Som daled til os ned,

Som til Gud Faders Ære

Vil Støvet klart hjembære

I Aandens Favnetag.

(PS VII, 475-476)

Det er flere likheter mellom kjærestenes kjærlighet og de sakrale relasjoner, blant annet denne: "Vort Liv er fælles Lyst!" i 3. strofe.

Grundtvigs bruderetorikk er et oppsiktsvekkende teologisk argument for hva kroppen betyr i alle former for kjærlighet. I sin tale ved graven til Lise, sin første kone, sier han blant annet:

Og alle de Mennesker, vi har elsket, har vi jo elsket i og med Legemet, og havde vi en fuldtro Ven og Veninde, da læste vi jo bedre og dybere Ting i deres Øje og Aasyn end de lærde i alle Stjærnerne, og vi fandt paa deres Læber ikke blot Legemets men ogsaa Sjælens Kys i det paa Kjærlighed rige Ord af Hjærtets Overflødighed; saa et evig Livs Haab, hvoraf Legemet er udelukt, det trøster intet menneskeligt Hjærte, som har Trøst behov, over Døden (Brandt 1877, 89).

I disse ord viser Grundtvig en mimetisk fortolkning av kysset, kroppen, det relasjonelle og evige liv - hinsides død.

\section{Bruden som prest}

Kan bruden, som kvinne, være prest? Kan hun som kvinne representere Kristus som brudgom? Ja, sa Grundtvig; og rokket dermed på tilvante og tabubelagte forestillinger. Spørsmålet om kvinnelige prester var et lite aktuelt tema på Grundtvigs tid. Riktignok var det en økt bevissthet omkring kjønnsroller i samfunnet. Men selv originale og nyskapende tanker om kvinnen begrenset hennes virkeområde til de private roller. Presterollen er en utpreget offentlig rolle. Grundtvig 
tumlet alvorlig med slike tanker, ikke minst ut fra en fromhetsretorisk synsvinkel. Det ser vi både i salmer, prekner og annen poesi. Et særlig godt eksempel finner vi i en preken Grundtvig holdt i $1870 .^{24}$

Det argumenteres her gjennom kvinnens forskjellighet og fortrinn, slik jeg tidligere har kommentert som en type erotisk, relasjonell betinget tale; i tillegg til eksempelfortellingene fra Jesu møter med kvinner. Dette fører han videre gjennom synet på kvinners roller $\mathrm{i}$ samfunnet. Når han så konkluderer med å oppmuntre kvinnene til å ta del i embetsgjerningen, er det også med grep fra hjerte og bruderetorikk: "at kun hvad der kommer fra Hjærtet gaar til Hjærte" og: "at Herrens Brud skal berede sig selv" (jf. note 24). Grundtvig uttrykker det å binde ledelse av kirken til ett kjønn som et stort tankekors han selv må gjøre noe mer, for kirkens troverdighets skyld og framtid.

Siden han rører ved tabubelagte, kjønnede bilder av Gud relatert til mennesket $i$ verden, varsler hans tanker for eksempel Mary Dalys klassiske påstand og korrektiv til den religiøse tradisjon når hun sier: "If God is male, male is God" (Daly 1973/86, 19). Dette var Grundtvig oppmerksom på. Et radikalt resultat av hans oppgjør med tradisjonen kan leses i følgende ord: "Derfor maa vi troende Mænd, langt fra at kyse de troende Kvinder, opmuntre dem til at tage Del i Embedsgjerningen" (jf. note 24).

\section{Bruden som Guds Datter}

Et annet av brudens ansiktstrekk er som Guds Datter. Hun opptrer i forskjellige sammenhenger. Noen ganger er hun en blant flere døtre. I en gjendiktning av kjorlighetens lovsang (1 Kor 1,13), er hun en personifikasjon av kjærligheten:

Vor Kiorlighed, den Blomme fiin,

Gud-Faders yngste Daatter,

Som kaldes alt i Vugge sin

En Dronning over Drotter,

Med himmelsk Ild i Jomfru-Bryst

Hun følger blindt sin Brudgoms Røst,

Skiøndt Vantro leer og spotter! ${ }^{25}$

Grundtvig gir henne liv og berettigelse på flere måter. I følgende strofe møter vi henne som brud. Guds Sønn er brudgom. De feirer gullbryllup. Denne gang er hun en personifisering av relasjonen mellom ordet og troen:

See til det skjulte Favnetag,

Ordets og Troens det bolde!

Vent paa den lange Sommerdag,

Naar de Guldbryllup holde! 
Brudgommen er Guds egen Søn, Bruden Guds Datter født i Løn, Salighed Ægteskabs-Glæden. ${ }^{26}$

Når Grundtvig i prosaform gir til kjenne tanker om hva/hvem Guds Datter er, kan det for eksempel få en form som i det følgende sitat, hentet fra en tale for en forsamling. Tema er analogien mellom Guds Sønn og Guds Datter:

Ja, de glædede sig i Hjertet, og Tusinder vil ved dem glæde sig tilligemed os, saa det bliver kundgjort over al Jorden, at her i vort Norden skabte Gud sig et andet lille helligt Land, hvor han aabenbarede sin Herlighed, her agtede han noget nær at fuldende hvad han begyndte langt borte, her vilde han paa en Maade aandelig opdrage den himmelske Faders Datter, ligesom han opdrog hans Søn i de galiloeiske Egne, i de smilende frugtbare Egne, som ogsaa der minde om, at Herren saae Alt, hvad han havde gjort, og se! det var Altsammen saare godt, det var godt og det vilde være blevet bedre, det var skjønt og det vilde være blevet skjønnere hver Dag. ${ }^{27}$

Her gjenkjenner vi Grundtvigs historiefilosofi, med storhetstiden langt tilbake, nedgangstid i mellomtiden, og en oppadstigende linje fram til egen tid. Vi gjenkjenner hans stedegne, situerte kristendomsforståelse.

Guds Datter som aktør i klassisk, mytologisk retorikk, med datterens og søsterens ansiktstrekk, kan vi se i følgende salme, en av de siste i Sang-Varket:

Som Maanen skinner af Solens Glands,

Saa Herrens Folk af Solaasyn hans,

Saa giennemskinnes paa Jorden Muld

I vore første Forældres Kuld.

Her Liv og Lys af Solaandens Æt

Hinanden røre i Ordet tæt,

I Mand og Kvinde de skilles ad,

Men det er ikke af Nid og Had.

Det er i det ædle Øiemed

At sammensmelte i Kiærlighed,

Hinanden de give deres Tro,

I Kiærlighed Eet kan vorde To.

De avle sammen i Lys og Løn

En Søster til Guds eenbaarne Søn,

En Aabenbaring, fuldskiøn og sand,

Af Jord og Himmel, af Gud og Mand.

Saa Sol og Maane, som Tro og Haab,

Gienfødes til Eet i Aandens Daab,

Og blive dertil i Aandens Favn 
Som Brudgom og Brud i Jesu Navn.

(GSV V, nr. 349).

At disse poetisk tradisjonsrike, billedrike og symboltunge tekster med fordel kan holdes tett sammen med Grundtvigs menneskebegrep, viser følgende sitat.

Det gjelder å være på vakt, sier han. Likeverdigheten mellom kvinne og mann forsømmes også $\mathrm{i}$ kirken:

skal til alle Tider minde om, at til det hele Menneske, som til den hele Menighed, hører lige saa vel Kvinde som Mand. Man skulde vel tænke, at hvem der kjender den hellige Skrift, behøvede ikke at mindes herom uden ved Skabelses-Bogen, som melder, at det var baade Mand og Kvinde, der skabtes i Guds Billede, og efter hans Lignelse; men kjender vi den sædvanlige Betragtning af Kvinden, selv midt i Kristenheden, da veed vi, det gjordes kun alt for hart behov at minde de Skriftkloge om Kvindens Jævnbyrdighed med Manden, lige saa vel i Henseende til de himmelske som til de jordiske Ting, og fremfor alt var det i den sidst forbigangne Tid aldeles glemt, at Kvinde-Hjærtet var Himlen lige saa nær som Menneske-Aanden; saa det skulde ingenlunde være det, Apostelen Pavlus vidnede om, da han skrev de mærkværdige Ord: at der er lige saalidt Mand uden Kvinde, som Kvinde uden Mand i Herren, altsaa i Guds-Mennesket, den anden Adam. ${ }^{28}$

Sammen med en salme som "Jord og Himmel at forbinde", hvor de symbolsterke og samtidig teologisk eksperimenterende uttrykkene Moder vor i Himmerig (2), Faderens eenbaarne Datter, Kjærligheden skjøn og prud, Evighedens Smil og Latter, Hun er Sønnens Ægte-Brud (4) forekommer, konfirmeres Grundtvigs religionsfilosofiske bidrag:

Jord og Himmel at forbinde

Ret med Kiærlighedens Baand,

Født dog af en Jøde-Kvinde,

Avlet af Guds Fader-Aand, Jesus Christus som Guds Ord

Kom med Kiød og Been til Jord.

Salig prise vi Marie,

Dig, som i dit Moder-Skiød

Gav Gud-Faders Søn at die,

Sammenvugged Aand og Kiød;

Salig frit og kalder sig

Moder vor i Himmerig.

Det er Troen, Aandens Kvinde, Hvem i Munden Du har lagt:

Jeg er Herrens Tjenerinde,

Skee mig alt hvad Du har sagt!

I mit Skiød da daler ned

Som Guldregn Guds Kiærlighed. 
Faderens eenbaarne Datter,

Kiærligheden skiøn og prud,

Evighedens Smil og Latter,

Hun er Sønnens Ægte-Brud,

Brudgom Himmel, Bruden Jord

Evig straale ved Guds Bord.

Derfor lyde skal Lovsangen

Fra den Christne Menighed,

Fremfor alt i Danevangen

Lige liflig op og ned,

Takten holder, høi og lav,

Kiærlighed i Fællesskab! ${ }^{29}$

I denne salmen begynner første strofe med en hyllest til jødekvinnen Maria ("Født dog af en Jøde-Kvinde"), som fødte Jesus Kristus, avlet av Guds "Fader-Aand", som tegn på at jord og himmel er forbundet (inkarnasjonen) i en kjærlighetsakt. Troen symboliserer i 3. strofe den kollektive form for Maria (de kristne, kirken, folkefellesskapene, sangskolene mm). Det som skjer i 4 . strofe, er at noe nytt blir til, "Faderens eenbaarne Datter", "Sønnens Ægte-Brud". Dette finner sted og forklares i siste strofe som det som skjer i "Danevangen" på Grundtvigs egen tid: "Den nordiske Menighed" (Grundtvig 1883, 92 ff).

Jeg oppfatter Grundtvigs mer eller mindre dunkle tanker om Guds Datter som en naturlig konsekvens av hele hans historiefilosofiske prosjekt, og et høydepunkt. Med dette sier han mer direkte og åpent hva det nye er, og hvordan han forstår dette som teologisk kulturanalyse.

En kan kalle det en fortsatt åpenbaring, hvor Gud på en annen måte enn før åpenbarer sine feminine sider. En slik kjønnet retorikk utvider og anfekter tradisjonell treenighetstenkning og kristologi. Gjennom dette får Grundtvig mot til å tillegge kvinnen en mulig offentlig, religiøs rolle som tidligere bare hadde vært tiltenkt menn.

\section{Hva med brudens dårlige sider?}

Vi har hovedsaklig møtt bruder med utpreget lyst til det gode, det sanne og det skjønne; og med skjebnesvangre fiendemakter å overvinne i kampen for kjærlighetens små og store seire. Det er mange tilkjempede lekser å lære underveis, i livslange prosesser.

Hvorfor møter vi ingen skildring av eller forakt for brudens uverdige sider i Grundtvigs retorikk? Hvorfor ingen nedlatende tale om bruden som uren, utro eller lignende?

I motsetning til tidligere og senere bruk av bruderetorikk, lar han seg ikke friste til å dyrke brudens mindreverdige sider. ${ }^{30}$ Han vet altfor 
godt hva mennesket $i$ verden er i stand til av godhet og ondskap, sannhet og løgn, skjønt og uskjønt. Bruden er attråverdig (for Gud). Hun er selv elskende (subjekt). Grundtvig fokuserer på menneskets kjærlighet, og våger bevisst å fordype seg $\mathrm{i} \mathrm{den.}{ }^{31}$ Det krever et helt annet mot enn å fordype seg i det motsatte. Hvis sår, feiltrinn og ondskap skal oppdages og behandles, sier han, må bekreftelsen alltid komme før avsløring, avvisning og mulig heling av det brutte forhold.

Han så faren ved bruderetorikk som fristelse og tilbøyelighet til å se ned på mennesket $i$ verden som den andre (både kvinne, mann og barn); implisitt på Gud selv (brudgommen) som kjarlighetens billedhugger (se ingress).

Han dekonstruerte noen av de stereotypiene som bruderetorikken var fanget $\mathrm{i}$, og brukte de på nye måter til det motsatte: å skaffe kvinnen nye rom i kulturen, mennesket (som mann, kvinne, barn) sin verdighet som elsket og elskende vesen, og en kreativ uro inn $i$ gudsbildene. $^{32}$

I Grundtvigs bruderetorikk dominerer liv og død-perspektivet over skyld og rettferdighets-perspektivet. Det gjør talen om mennesket $i$ verden til en ærefull tale om dets gode, sårbare, og onde sider. Det er en særlig forbilledlig talemåte i kampen for menneskets alltid truede ære; og dermed Guds: "Det giælder og din Ære". ${ }^{33}$ Slik ivaretar Grundtvig tilliten til brud og brudgom, som menneske og som Gud.

\section{Forkortelser}

GSV I-VI: Th. Balslev et al.(udg.) (1944-66), Grundtvigs Sang-Vark. Samlet Udgave, bind 1-6. København.

US I-X: Holger Begtrup (udg.) (1904-09), Nik. Fred. Sev. Grundtvigs

Udvalgte Skrifter, bind 1-10, København.

\section{Litteraturliste}

\section{Værker af Grundtvig}

Balslev, Th. et al. (1944-1964), Grundtvigs Sang-Vark. Samlet Udgave, bind 1-6, København.

Begtrup, Holger (utv.) (1904-09), Nik. Fred. Sev. Grundtvigs Udvalgte Skrifter, bind 10, København.

— (red.) (1924), Vartov-Proedikener 1839-1860, København.

Brandt, J. C. (utv.) (1880), Grundtvigs sidste Prodikener, bind 2, København

(red.) (1877), Kirkelige Leilighedstaler af N. F. S. Grundtvig, København. 
Grundtvig, N. F. S. (1817a), "Om Mennesket i Verden” i Danne-Virke, et Tids-Skrift, bind 2, København.

— (1817b), "Om Sandhed, Storhed og Skiønhed" i Danne-Virke, et Tids-Skrift, bind 3, København.

- (1837), Sang-Vark til den Danske Kirke, København.

- (1883), Kristenhedens Syvstjarne, udg. C. J. Brandt, Svend Grundtvig, Skat Rørdam, P. Schjørring, København.

Grundtvig, Svend et al. (utv.) (1880-1930), N. F. S. Grundtvigs Poetiske Skrifter, bind 8, København.

\section{Værker af andre forfattere}

Arndal, Steffen (1989), Den store hvide Flok vi see: H. A. Brorson og tysk pietistisk vakkelsessang, Odense.

Balslev-Clausen, Peder (1983-84), "Det kvindelige som motiv i Grundtvigs Sang-Værk (1837)", Hymnologiske Meddelelser. Artiklen meddeles i 1983, nr. 4, 245-278, og i 1984, nr. 1-2, 3-24.

— (1987), “"Mødrene-Arv fra Paradis'. Om Grundtvigs kvindesalmer i 'Den Danske Salmebog'”, Proesteforeningens Blad (20), årg. 77, 381-394.

Beckman, Ninna Edgardh (2003), "Guds tal eller vårt, Vägar bortom ett inklusivt gudstjänstspråk", Sven-Åke Selander (red.), Svenskt Gudstjänstliv, årg. 78/2003, Liturgi och språk.

Daly, Mary (1973/86), Beyond God the Father. Towards a Philosophy of Women's Liberation, London.

Elbek, Jørgen (1960), Grundtvig og de grceske salmer, København.

Heggem, Synnøve Sakura (2003), "Salmetradisjon og bruderetorikk" i

Solberg, Baklid, Fjågesund (red.), Tekst og tradisjon, M. B. Landstad 1802-2002, HiT, skrift 4/2003, Porsgrunn.

— (2005), Kjarlighetens makt, maskerade og mosaikk. En lesning av Grundtvigs Sang-Vark til den Danske Kirke, Oslo.

King, Ursula (2001), Christian Mystics. Their Lives and Legacies througout the Ages, New Jersey.

Lundgren, Eva et al. (red.) (1982), “...når verdens horelatter blir til brudens frydegråt", Den bortkomne datter. Kvinneteologi, kvinnefrigjøring og teologikritikk, Oslo.

Nørager, Troels (1996), Hjerte og Psyke. Studier $i$ den religiøse oplevens metapsykologi og diskurs, Frederiksberg.

Stevns, Magnus (1950), Fra Grundtvigs Salmevarksted, København

Svenungsson, Jayne (2004), Guds återkomst. En studie av gudsbegreppet inom postmodern filosofi, Munkedal.

Toldberg, Helge (1950), Grundtvigs Symbolverden, København. 


\section{Offisielle salmebøker}

Evangelisk-kristelig Psalmebog (1798), København.

Landstads Salmebok (1871), Kristiania.

Landstads Reviderte Salmebok, (1924), Oslo.

Norsk Salme Bok, (1985), Oslo.

\section{Noter}

Grundtvig 1883, 156.

Betraktningene som følger er hentet fra Heggem 2005.

Grundtvig framstiller disse språksamfunn eller sangskoler i ulike sammenhenger. En kortfattet versjon kan leses i innledningen til Kristenhedens Syvstjorne (1883), "Indledning", VI-VII.

4 Se ingress over.

5 Se videre i Heggem 2005, 70-88.

6 Se for eksempel King 2001; Arndal 1989, 211-225; Nørager 1996, særlig om hjertemetaforikken, 66-102: "Det kristne hjertesprog".

7 Et eksempel, som Grundtvig ved flere anledninger henviser til, er rasjonalismens autoriserte salmebok, Evangelisk-kristelig Psalmebog som kom ut i 1798. En nedtoning av f.eks. bruderetorikken kan leses ut av denne samling salmer. Grundtvig sier blant annet at den rasjonalistiske smak finner brudebilder som altfor dunkle og uklare.

8 Teologisk og filosofisk er dette også uttrykk for Grundtvigs tradering av og oppgjør med fortiden. Mens Augustin og den katolske tradisjon har en særlig forkjærlighet for naturkategorier (natur/nåde) i framstilling av mennesket i verden som Gudskapt, har Luther og tradisjonen etter han en vektlegging på juridisk metaforikk (simul justus et peccator). Grundtvig vektlegger på en helt ny måte de kroppslig/kjønnede/relasjonelle metaforer i framstillingen av mennesket $i$ verden.

Til kvinnebilder hos Grundtvig, se også Stevns 1950, $72-85$ og BalslevClausen 1987, 381-394, og 1983, nr. 4, 245-270, og 1984, nr.1-2, 3-24. Grundtvig, "Et Blad af Jyllands Rimkrønike", sitert i Toldberg 1950, 45. Grundtvig 1883, 119.

"Ingen har Guldtaarer fældet, / Som ej Glimt af Guldet saa" (Grundtvig 1883, 106).

13 Salmetekstene er særlig ment som tekster til speiling. Samtidig som Grundtvigs oppfattelse av ord i seg selv som bolig, redskap og speil alltid spiller på speilingsmuligheter uansett genre.

14 Grundtvig, Dansk Ravne-Galder 1860, US X, 401. Om påvirkning fra Østkirkens kvinnefromhet, se f.eks. Elbek 1960. GSV IV, nr. 224.2 ("Alt hvad som Fuglevinger fik"). GSV I, nr. 56.6 ("I Begyndelsen var Ordet"). GSV I, nr. 62.1. GSV I, nr. 92.25 ("Fader-Vor er Herrens Bøn”). Grundtvig 1883, 119. 
Se over, siste strofe i GSV I, nr. 105.

Jørgen Elbek har tydeliggjort dette, f.eks. i følgende sitater: "Grundtvig går ind i lignelsens situation, og det er, som om det, at han taler gennem en kvindes mund, har givet hans bøn en opreven lidenskabelighed, som han dårligt kunne bringe over sine egne læber."

"Kvindens følelsesrige væsen bliver medium for salmistens bøn til Herren og lægger skønhed over bønnens situation, som mellem mænd gerne kunne være uudholdelig" (Elbek 1960, 96). GSV IV, 13-15 ("Ser jeg op til Sol og Maane").

Min uthevning.

Svend Grundtvig (1880-1930), bind 8, 294-295. De tre første strofer går slik:

Underligt er vort jævne Land,

Alfer omsvæve dets Skove,

Og under Fuglesang ved Strand

Havfruer danse paa Vove;

Særsynet kommer som en Tyv,

Skov! fra dit Skjul og Havets Dyb!

Kvindeligt er vort Modersmaal,

Skjoldmø kun der under Vaaben,

Kraften er Kys og Dyden Taal,

Vid titter ud under Kaaben,

Som i et Moderskjød ogsaa

Myldrer det tit af Skjalde smaa.

Lykkelig er den lille Skjald,

Graalig med Lærkernes Tunge,

Thi for hans Vugge - tre i Tal -

Alfernes Norner de sjunge:

Hvad dig end brister, op og ned,

Vis er dig Kvindens Kjoerlighed!

\section{J. C. Brandt 1880, 261-263}

GSV I, 11 ("Til klart Guds Ansigt vi skal see").

Grundtvig, Ordet og Troen, 1857. Sitert i Toldberg 1950, 107.

Grundtvig, Fra Vennemødet 1868, 10.9. Sitert i US X, 560-561.

Brandt 1880, bind 2, 163-164: "Søndag mellem Jul og Nyaar 1868". GSV V, nr. 338.

Med "tidligere og senere bruk av bruderetorikk" mener jeg f.eks. deler av Brorsons retorikk og forsøk på å fornye denne talemåte i norsk salmediktning (f.eks. Børre Knudsen). Kritikk mot bruderetorikken kan en f.eks. lese i Beckman 2003, når hun i prosjektet inkluderende språk i gudstjenesten sier: "Traditionell brudmetaforik förefaller i detta sammanhang både otillräklig och olämplig, dels på grund av den inbyggda heterosexuella normativiteten och dels på grund av kopplingen til könsbundna system av över- och underordning". 
Kritikk av nyere forsøk på å gjenopplive bruderetorikken kan også leses i Eva Lundgren (1982), "når verdens horelatter blir til brudens frydegråt", 124-130.

Se ellers til Heggem 2003, hvor jeg tar for meg endringer i bruderetorikken fra Landstads Salmebok, over Landstads Reviderte Salmebok til Norsk Salme Bok.

31 Se f.eks. følgende sitat: "Med Varmen i sit Inderste og Glandsen i sit Aasyn er det naturlige Menneske i Sandheds Øine et Billede af Kiærligheden, men her komme vi atter til det store Spørgsmaal, om Mennesket har lært at betragte sig saaledes, og om han har fordybet sig i denne Betragtning!" (Grundtvig 1817b, bind 3, 47).

32 Når jeg sier dekonstruere, så er det fordi jeg oppfatter Grundtvigs bidrag til dette som svar på den kritikk som kan reises mot moderne dekonstruksjon av gudsbilder (f.eks. Derrida, Marion og Levinas). Kritikken knyttes særlig til fravær av kjønnsbestemt oppfattelse av gudsbegrepet. Se Svenungsson 2004, 204-238. Se også Heggem 2005. GSV I, 4 ("Christi Kirkes Alderdom”). 